\section{Going back to collections: a study case of the Florentino Ameghino collection housed in the Museo de La Plata (Argentina)}

\author{
De volta às colecções: 0 caso da colecção \\ Florentino Ameghino do Museu de La Plata \\ (Argentina)
}

\section{KARINA VANESA \\ CHICHKOYAN 1}

IIDyPCa, Conicet, UNRN, Mitre 630, 8400 San Carlos de Bariloche, Río Negro, Argentina INIGEO, Universidad Nacional de Luján, Ruta Nacional 5 y Avenida Constitución, 6700 Luján, Buenos Aires, Argentina karinavch@gmail.com

\begin{abstract}
The historical Florentino Ameghino collection housed in the Museo de La Plata (Argentina) joined the 19th century international discussion about human antiquity. The collection comprises bones with evidences of anthropic modification from alleged Tertiary beds associated with extinct animals. According to the Argentinean naturalist Florentino Ameghino, these evidences proved the early presence of humans in the South America's Southern cone. This analysis rules out the proposed intentionality behind the anthropic traces. Instead, most of the materials were remains of broken bones for marrow extraction. The revision of these historical collections is therefore crucial for obtaining up-to-date information to advance in current researches as methodologies to study them had highly developed in the last century. In this sense, museum collections become an alternative and powerful firsthand tool that preserves our non-renewable record of the past.
\end{abstract}

\section{Resumo}

A colecção histórica Florentino Ameghino, alojada no Museu de La Plata (Argentina), fez parte da discussão internacional do século XIX sobre a antiguidade humana. A colecção compreende ossos, de alegados estratos do período Terciário associados a animais extintos, com marcas de modificação antrópica. Segundo o naturalista argentino Florentino Ameghino, essas evidências comprovavam a presença precoce de seres humanos no cone sul da América do Sul. Esta análise descarta a intencionalidade dos traços antrópicos. Em vez disso, considera que a maioria dos materiais eram restos de ossos quebrados para extracção de medula óssea. A revisão dessas colecções históricas é, portanto, crucial para obter informações actualizadas que permitam avançar as pesquisas atuais, pois as metodologias para estudá-las foram significativamente desenvolvidas no último século. Nesse sentido, as colecções de museus tornam-se uma alternativa e uma poderosa ferramenta de primeira mão que preserva o nosso registo não renovável do passado.

\section{KEYWORDS}

Historical collections

Archaeology

Preservation

South America

Human Antiquity bones

\section{PALAVRAS-CHAVE}

Colecções históricas Arqueologia Preservação América do Sul Ossos humanos da Antiguidade 


\section{Introduction}

The issue of human antiquity has been developing in Europe since at least the 17th century, but only in the 1860 a certain consensus was reached [1-5]. Extinct mammals and archaeological remains, associated in undisturbed beds, was the main evidence for proving a deep human past [1, 5-7]. North America played an active role, mostly during the second half of the 19th century [3, 8]. Claims of early human presence in South America can be traced to the 1840s, but they had a greater importance in the last decades of the 19th and early 20 th centuries $[3,7,9]$. In this continent, native human remains provided during the expansion into indigenous lands were used for questioning the antiquity of man, just as it happened in Argentina [7, 10].

Hermann Burmeister and Francisco P. Moreno were among the first scientists who dealt with this issue $[3,10]$. But Florentino Ameghino combined archaeological, paleontological and geological evidences to suggest that humans were present at the South America's cone since Tertiary times [3, 11-13]. In order to sustain his challenging idea, he presented a series of paraderos (temporary hunter-gatherer sites) he himself excavated in the 1870s. They were located in the Luján River Basin, in the surroundings of what today are the cities of Mercedes and Luján, in the Northeastern Pampean region of Argentina [3, 11-13] (Figure 1 [14]). A detailed description of associated worked bones and lithics, allegedly placed on Pliocene beds, was presented in his first works and especially explained in his masterpiece La Antigüedad del Hombre en el Plata (1880-1881). In addition, a series of anthropically modified bones plus non-modified bones belonged to megamammals species [11], confirming human coexistence with extinct fauna and therefore human antiquity [3, 12]. But his theory was rapidly dismissed, especially by the Czech anthropologist Hrdlička who showed that the material presented by Ameghino was modern [7, 15-18]. Nevertheless, Ameghino's proposal that first human groups coexisted and exploited megamammals in the Americas proved to be true with the discovery of North American sites during the first decades of the 20 th century $[8,12]$.

This historical context highlights the importance of the Florentino Ameghino collection in the conformation of museological collections of the 19th century. Arguments favoring or detracting its validity as evidence of early human presence in South America crosses over each element of this collection. Ameghino especially described the bones, as he needed to prove that they had been humanly transformed [11]. To do so, he classified and evaluated the different functions each fragment had. However, the current review of them has shown evidences of bone processing, especially for marrow extraction. During 1870s-1880s, bones analyses were still unusual in the archaeology of Argentina [19], even though they were becoming common in the European longtradition of paleontological and archaeological research, and had highly advanced during the 2oth century [1, 6, 13, 20-22]. Consequently, collections originated during the 19th century or before are a valuable resource to be restudied with present-day methodologies. As this material has been interpreted in a faraway historical and scientific context, they are susceptible of having new information, or previous

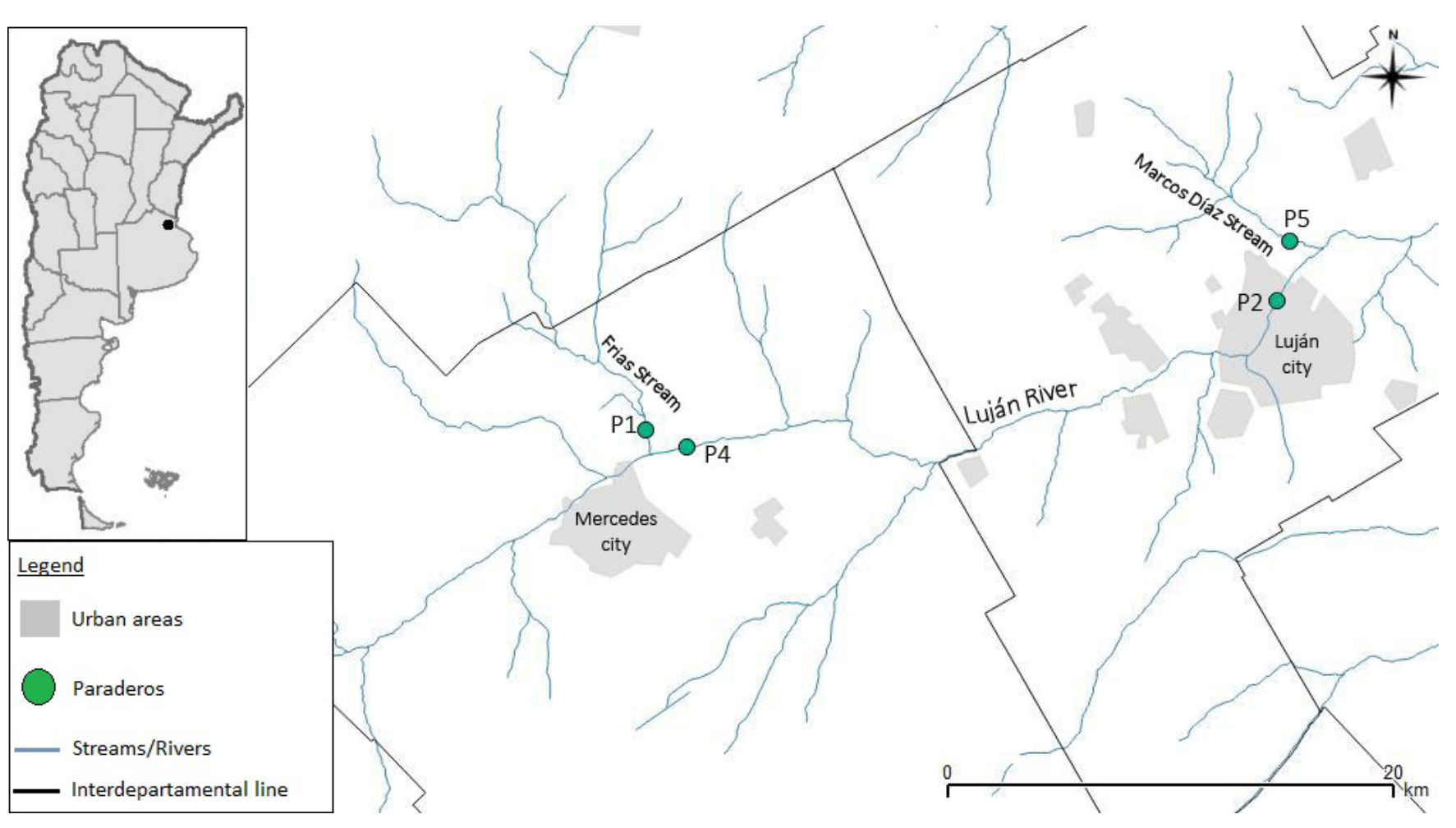

Figure 1. Location of paraderos 1, 2, 4, 5 presented by Ameghino (Map based on [14]). 
interpretations can be reviewed under the light of new methodological approaches [6, 20, 23-28]. Therefore, with the incorporation of the taphonomical background and zooarchaeological concepts [19, 21-22, 29], the initial interpretations of these historical collections are out-of date.

The revision of the Florentino Ameghino collection was based on this perspective and it was part of a project that involved reviewing Argentine and European historical fossil collections using novel methodologies [20]. This analysis brings back a historical collection that was a key element in the worldwide controversy of early human occupation in South America. In addition, it is one of the few still available evidences to understand prehistoric occupations in an area highly impacted by modern urbanization [12] (Figure 1). Hence, the aim of this work is to present the new analysis of the Florentino Ameghino collection, contextualized into the 19th century discussion of human antiquity. The ultimate objective is to revalorize this patrimony for current research issues through the use of next-generation methodologies and perspectives. The integration of this Cultural Heritage into new study programs is a necessary step for scientific and public requirements. Moreover, it is a way of preserving our patrimony given the fact that the record of the past is a non-renewable resource [24-25, 30].

\section{The Florentino Ameghino collection and human antiquity}

For the science developed in Europe in the 19th century, the issue of human antiquity had religious, philosophical and scientific connotations. Ensuring the non-existence of a prediluvial man confirmed the Bible scriptures. According to the geological studies of that period, humans arrived to a modern Earth, where a succession of catastrophes modeled the surface and extinguished megamammals communities [1-2, 4-6]. Consequently, the presence of extinct mammals and the geological position of bones and/or anthropic remains were crucial evidences for discussing the age of humans. To this, methodological and theoretical tools to analyze the variability of past material culture and faunal remains started to be developed. Observation of the stratigraphy and finding associations of materials in the same levels were especially relevant $[1-2,4-6]$. Also, early post-depositional and taphonomical observations started to emerge to unravel site formation and biological agents marking bones surfaces $[1,6,19,21,29]$. By 1850s-1860s, several paleontological, geological and archaeological advances had taken place. Thus, the great antiquity of man and its coexistence with megamammals started to be accepted, contradicting early views on this subject [1-6].

By the second half of the 19th century, the Natural Sciences of North America also began to question the antiquity as well as the origin of Native Americans. Political and ideological issues and the existence of indigenous people influenced the acceptance of a deep time human occupation in the Americas [3, 8]. As a result, most of the evidences pointing to humans and extinct fauna coexistence and/or human remains into antique geological beds were dismissed $[3,8,15]$. The settlement of the Americas was recent in time, in contrast to the ultimate European vision of humanity great antiquity $[8,15]$. Only in 1927 megafauna-humans coexistence and an older American human presence started to be accepted with the discovery of associated bison bones and artifacts in the Folsom site (New Mexico, USA) [8].

North America and Europe were the main centers of academic discussion [1, 3, 8, 31], so South America's southern cone's claims of human antiquity were not considered [7]. Peter W. Lund, a Danish naturalist, broke this polarization with his pioneering work in Lagoa Santa (Brazil). His excavations in different caves of this place resulted in the first assertion of South American human-megafauna antique association. However, only in the late 19th and early 2oth centuries, his thesis started to be discussed internationally $[3,9]$. In Argentina in the 1870s, Burmeister and Moreno were among the first researchers to discuss an old human origin in the South American continent. Their assumptions mixed up with political interests for building a national discourse of the emerging state [3, 10, 31]. By that time, Ameghino was also aiming to prove the great antiquity of humans. But his view was more related to a general Natural Science discipline influenced by the evolutionist paradigm [31-32]. After the 1880's, he went even further into his theories by suggesting America as the cradle of humankind (3, 16, 18, 31-32]. This late postulate was aligned with the renewed questions about origins, evolution and dispersion of humans due to the discovery of different hominids skeletons in the Euro-Asiatic continent by the late 19th and early 20 th centuries [2, 31-32]. For proving his novel ideas, and following European trends of new discoveries [3], Ameghino described different human remains and lithic industries. These evidences were the most debated at national as well as international levels $[7,13$, 15-18, 31-32].

But for his first postulates Ameghino relied on a set of bones and lithic artifacts. He excavated this material between 1869 and 1877 in different paraderos, while being a schoolteacher in Mercedes city [12]. He registered the general context (association of bones, tools and geological levels), recorded small fragments of bones and described and classified them according to the type of surface modification he observed [11, 19]. Since his goal was to prove a Pampean long-term human occupation and coexistence with extinct fauna, he linked archaeological, paleontological and geological evidences and considered taphonomical insights for understanding site formation and origin of the marks on bones surface $[13,19,33]$. This circuit of meticulous excavation by levels or layers, registering contextual information and interpretation of the material was still an unusual way of analysis in South America, as compared to the European developments mentioned above. 
Regarding the description of bones, he assumed that most of the materials, especially the small fragments, had been intentionally worked for specific purposes. But despite the detailed explanation of each one, certain bones attributed to instruments were actually fragments detached from the bone processing activity. Consequently, modern perspectives must be applied to these first analysis attempts. After the initial advances of the 19th century, a whole framework for studying bone material (including conceptual, technological and experimental axis) started to develop and expand, especially after the 1970s [5, 21-22, 29]. Taphonomical reasoning began to be incorporated to differentiate the several surface modifications produced in bones after animals die [21, 34-35], for differentiating non-biological activity (e.g. postdepositional fractures, sediment, fluvial intervention, trampling, weathering, roots, manganese spots) from biological intervention (carnivores and humans) [21-22, 34-35]. As a result, the corpus of procedures that archaeology has developed throughout these decades has been useful for going back to these old collections. They can be reviewed with the new technological advances and obtain new information under the modern standards of scientific knowledge.

\section{Are museum collections suitable materials for current research?}

Historical collections are a testimony of how the prehistoric science was shaped during the 19th or earlier centuries [2]. In those times, natural and cultural patrimonies were part of different trading networks among local authorities, voyagers, intermediaries and museums $[3,36]$. Fossils, botanical remains, faunal species, ethnographical objects and even architectural features have rested in these institutions to date $[22,26,30,36-37]$. As a result of this handling, most historical collections are disassociated with their principal context of provenance and/or chronology. Some materials only have a regional assignment, they are isolated objects or, in the faunal cases, their taxonomic designations are outdated. They also suffer from representativeness, as the most complete or beautiful pieces have been selected without considering the context or the associations [20, 23, 25, 27, 37-38]. The types of curation and conservation strategies of the past could have blurred, covered or destroyed specific attributes for current analysis [23, 37-38]. Especially over the last 150 years, loss of records and documentation, removal of the deposits and even wars have deteriorated the fragile contextual association of these collections $[20,27,38]$.

Despite these debilities, this patrimony can be interbred in current research studies. Indeed, it is true that the information obtained will not have the same resolution as the systematic excavated materials. It can also be hard to interpret them into archaeology realms, where contextual information is basic for making assumptions [20, 22, 24-25, 27, 38]. The little contextual information these types of collections have as associations, stratigraphy position or sedimentary matrix opposes a fine-grained analysis, and data interpretation will be limited. Nevertheless, these historical collections are a highly valuable resource for different reasons:

1. They are firsthand resources that can save money and time, as the raw data have already been collected [39]. As a consequence, space, staff and curational resources must be used to properly maintain them [23, 37-38]. Collections need to be preserved in a special place: its maintenance depends not only on the individual packaging (e.g. bags or boxes) but also on the storage area. Specialists from different disciplines must be dedicated to different aspects of their preservation. Supplies, special instruments and tools must be used for maintaining collections for future generations. These necessary resources are generally paid through public taxes $[26,30$, 39]. Thus, the use of collections in current analyses is also a way to work for the societies that indirectly maintain them.

2. These historical collections are sometimes the only way we have to research the past of the earth variability. Sites where the archaeological and/or natural material was extracted from, or the groups that made the material culture, may not exist anymore $[12,30,40]$. In this sense, the past is a non-renewable resource as field work is not only a data-collective activity but also a destructive procedure [24]. Modern urbanization can cover or remodel sites excavated in the 19th century or earlier, $[12,40]$ and also destroy the current ones. In addition, some 19th century-plundered indigenous populations have disappeared or transformed from the time their material culture was distributed around the world [30].

3. As mentioned before, these collections can still contain information that was ignored or interpreted in different ways, given the historical context and the existing methodologies prevailing at the time of their recollection.

Therefore, incorporating historical collections into current research programs revalue this type of patrimony. Studies carried out in different time periods are reconnected, historical information surrounding the conformation of the collections is rescued and new information is obtained. In this sense, in the last decades, the collections of lithics, ceramics and fossil materials started to be used in current study programs [6, 20, 24-25, 27-28]. Consequently, these materials are proving to be a necessary option to produce novel knowledge for present and future studies regarding our past behavior. Under this perspective, and considering the historical debate in which the Florentino Ameghino collection has been described, its current revision has been a necessary task.

\section{Material and methods}

The Florentino Ameghino collection is housed in the Depósito 25 of the División de Arqueología of the Museo de La Plata (Argentina) (MLP-Ar). This museum is one of the most important institutions of this type in that country. It was founded under the late 19th worldwide emerging trend 
of development of Natural Science museums and consequently, it houses crucial archaeological, anthropological and paleontological collections constituted at that time [36]. Currently, the División de Arqueología has a program for recovering and revaluing the historical collections deposited in this area [41].

This collection was the onset of Ameghino's proposals regarding human presence in Tertiary levels in coexistence with extinct megamammals [3, 11-13]. Given the effect these ideas had on the scientific local community, he took the collection to the International Exposition held in Paris in 1878. There, the material was given a special location and was examined by different international researchers [3, 11-13, 18]. Having been brought back to Argentina, the collection was housed in the Museo de La Plata [11-12] and reviewed by Lehmann-Nitsche [42]. To this author, bone fragments were mostly accidental splinters. Afterwards, the collection was misplaced for several years and nowadays only part of it has been recovered [12-13].

Biological marks made by humans when processing the animal were differentiated from carnivores or non-biological activity. On the one hand, when separating the different muscles and tendons of the animals, cut marks can be left in bone surfaces [21, 34-35]. In general terms these marks are elongated, linear and narrow [21, 34-35] and they are presented in patches or clusters, with parallel or similar orientation among them $[21,35]$. Besides, humans fracture bones in order to access the marrow [21-22], leaving broken bones with spiral (or longitudinal) morphology with a smooth surface $[21,35]$. In addition, impact points can be left in the breakage sequence. These are depressed semicircular areas indicating the pressure of the stone collapsing the bone [21, 34-35]. Internal circular traces can be present in the semicircle [21]. Flakes and/or percussion cones can be detached by the blow upon the bone, or they can remain adhered [34-35]. Detached flakes can leave extractions in the cortical or medullar faces.

These current classifications were considered for each piece of bone so as to give an up-to-date interpretation of the collection. Nevertheless, the original categories suggested by Ameghino were respected. Three categories were especially important in his analysis: "bones longitudinally broken" referred to fragments obtained after the percussion for extracting marrow. Fragments of these bones could eventually be transformed in instruments thus entering in the category of "worked bones". Finally, when the bones presented cut marks they were classified as "bones with incisions" [11, 19]. Additionally, the author assigned other bones to categories such as "mandibles broken by man", "burned bones" and "bones with signs of having been struck" that were not present when the analysis was made. The material was reviewed with the naked eye and then with $3.5 \times$ and $12 \times$ magnifying glasses. In addition, a Dinolite Microscope 4113 model and its software (Dinolite 2.0) were also used. High resolution photographs were taken with a Panasonic Lumix DMC-TZ35 camera.

\section{Results}

The material analyzed here belongs to the paraderos $1(\mathrm{PI})$, 2 (P2), 4 (P4) and 5 (P5) (Figure 1). A total of forty-six bones were reviewed, thirty-eight presented clear anthropic interventions while the rest could not be assigned to current classification of anthropic breakage (Table 1). In general, the material presented a good level of conservation, with conserved cortical bone and a low degree of post-depositional factors. The most important modifications found were spots of sediment and manganese, and weathering. Spots of manganese were small and very disperse, except for six bones where they covered most of the surface. Sediment was also present in a very disperse way, without forming concretions, with the exception of two bones. Low levels of weathering, consisting of just few cracks were observed. In some cases they were placed over the anthropical fractures, indicating that the bones had been shortly exposed after their manipulation.

The bones reviewed in the four sites were the result of different anthropic activities for extracting marrow, flesh and probably to produce instruments: twenty-one fragments, twelve flakes, three percussion cones and two cut-marked ribs were differentiated (Table 1).

\section{Paradero 5}

It was composed of an important deposit of bones such as cervids, guanacos and extinct animals such as Toxodon and Glyptodon, plus human industry. It was found by Ameghino 1.5 to 2 meters below the surface of the Marcos Díaz stream [11] (Figure 1). Eight elements were reviewed from this site, including diaphyses of medium and small mammals and two indeterminate fragments (Table 1). According to the author, most of the broken diaphysis belonged to cervids and guanacos.

Of the three suggested categories, only "bones longitudinally broken" and "worked bones" were identified in the collection. The first one was made up of the MLP-Ar-(b)622/3 fragment and according to the author's interpretation, it was likely to be the consequence of marrow extraction. Rodent marks, probably of Reithrodon, surrounding the entire bone surface were found by Ameghino. However, these marks can be nowadays reinterpreted as the result of root action. Dendritic, U-shape pattern is left by this nonbiological intervention, as observed in this element (Figure 2a). Interestingly, the author observed that the alleged rodent marks were made after the bone was humanly broken. He specifically described the marks extended over the surface and into the medullar canal. The superposition of different factors taking place in the bones was an observation systematized much later, in the 2oth century.

Currently, it is used to indicate that cut-marks are antique when other post-depositional factors cross over them [34]. The other seven bones correspond to the second category, "worked bones". Nevertheless, several sub-categories were 
made by the author. Some bones were first longitudinally broken and subsequently worked to obtain sharp edges to be used as instruments. These were the cases of bones MLP-Ar-(b)591-592, MLP-Ar-(b)601, MLP-Ar-(b)609 and MLPAr-(b)626-627 that would have been instruments for cutting, scrapers for cleaning skins or awls. Bones MLP-Ar-(b)634-635 and MLP-Ar-(b)628/9 were classified as arrowheads because of their small shape and polish, for obtaining a sharp edge. A third sub-category consisted of very small fragments of bevel-cut bones (bone MLP-Ar-(b)593-95) in spite of the fact that Ameghino could not clarify the specific function of this type of instrument. However, the current identification of spiral fractures, impact points, adhering flakes or extraction attributes, allows to assign five bones (MLP-Ar-(b)591-592,

Table 1. Detail per paradero of the Florentino Ameghino collection, indicating Ameghino's description and an alternative interpretation.

\begin{tabular}{|c|c|c|c|c|c|c|c|c|c|c|c|c|c|}
\hline \multirow[b]{2}{*}{ Number } & \multirow[b]{2}{*}{ Site } & \multirow[b]{2}{*}{ Element } & \multirow[b]{2}{*}{$\begin{array}{l}\text { Size / } \\
\text { identi- } \\
\text { fication }\end{array}$} & \multirow[b]{2}{*}{ Ameghino category } & \multirow[b]{2}{*}{$\begin{array}{l}\text { Specific function according } \\
\text { to Ameghino }\end{array}$} & \multicolumn{3}{|c|}{$\begin{array}{l}\text { Alternative } \\
\text { interpretation }\end{array}$} & \multicolumn{5}{|c|}{$\begin{array}{l}\text { Additional characteris- } \\
\text { tics of bone processing }\end{array}$} \\
\hline & & & & & & 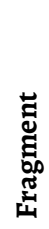 & $\frac{\stackrel{0}{\pi}}{\frac{\pi}{4}}$ & 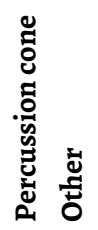 & 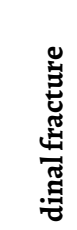 & 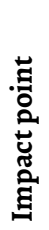 & 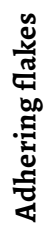 & : & 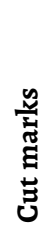 \\
\hline MLP-Ar-(b)622/3 & $\mathrm{P}_{5}$ & Diaphysis & Medium & Bone longitudinally broken & Bone broken for marrow extraction & 1 & & & 1 & 1 & & & \\
\hline MLP-Ar-(b)591-592 & $\mathrm{P}_{5}$ & Diaphysis & Small & Worked bones & $\begin{array}{l}\text { Instrument for cutting or } \\
\text { scraper for cleaning skins }\end{array}$ & 1 & & & 1 & 1 & & & \\
\hline MLP-Ar-(b)601 & $\mathrm{P}_{5}$ & Diaphysis & Medium & Worked bones & Instrument for cutting or awl & 1 & & & 1 & 1 & 1 & & \\
\hline MLP-Ar-(b)634-645 & $\mathrm{P}_{5}$ & Diaphysis & Small & Worked bones & Arrowhead & 1 & & & 1 & & & & \\
\hline MLP-Ar-(b)628/9 & $\mathrm{P}_{5}$ & - & - & Worked bones & Arrowhead & & 1 & & 1 & & & 1 & \\
\hline MLP-Ar-(b)593-95 & $\mathrm{P}_{5}$ & - & - & Worked bones & Bevel-cut instrument & & 1 & & 1 & & & & \\
\hline \multirow[t]{2}{*}{ MLP-Ar-(b)626-627 } & $\mathrm{P}_{5}$ & Diaphysis & Medium & Worked bones & Scraper & 1 & & & 1 & 1 & & & \\
\hline & & & & & & 6 & 2 & & 8 & 4 & 1 & 1 & \\
\hline MLP-Ar-(b)596 & $\mathrm{P}_{4}$ & Diaphysis & Medium & Bone longitudinally broken & Bone broken for marrow extraction & 1 & & & 1 & & & 1 & \\
\hline MLP-Ar-(b)581-582 & $\mathrm{P}_{4}$ & Diaphysis & Small & Bone longitudinally broken & Bone broken for marrow extraction & 1 & & & 1 & & & 1 & \\
\hline MLP-Ar-(b)612 & $\mathrm{P}_{4}$ & Diaphysis & Medium & Bone longitudinally broken & Bone broken for marrow extraction & 1 & & & 1 & 1 & & & \\
\hline MLP-Ar-(b)621 & $\mathrm{P}_{4}$ & Diaphysis & - & Worked bones & Arrowhead & & 1 & & & & 1 & & \\
\hline MLP-Ar-(b)640 & $\mathrm{P}_{4}$ & Diaphysis & - & Worked bones & Arrowhead & & 1 & & 1 & & & & \\
\hline MLP-Ar-(b)562-563 & $\mathrm{P}_{4}$ & - & - & Worked bones & Arrowhead & & 1 & & & & & 1 & \\
\hline MLP-Ar-(b)618 & $\mathrm{P}_{4}$ & - & - & Worked bones & Arrowhead & & & 1 & & 1 & & & \\
\hline MLP-Ar-(b)540-541 & $\mathrm{P}_{4}$ & Diaphysis & Medium & Worked bones & Arrowhead or awl & 1 & & & 1 & & & 1 & \\
\hline MLP-Ar-(b)583 & $\mathrm{P}_{4}$ & Diaphysis & Medium & Worked bones & Bevel-cut instrument & & 1 & & 1 & & & & \\
\hline MLP-Ar-(b)585 & $\mathrm{P}_{4}$ & Diaphysis & Medium & Worked bones & Bevel-cut instrument & & 1 & & 1 & & & & \\
\hline MLP-Ar-(b)553 & $\mathrm{P}_{4}$ & Diaphysis & - & Worked bones & Bevel-cut instrument & & 1 & & & & & 1 & \\
\hline MLP-Ar-(b)559-561 & $\mathrm{P}_{4}$ & Diaphysis & - & Worked bones & Bevel-cut instrument & & & 1 & & 1 & & & \\
\hline MLP-Ar-(b)549-550 & $\mathrm{P}_{4}$ & Diaphysis & Medium & Worked bones & Bevel-cut instrument & 1 & & & 1 & & & & \\
\hline MLP-Ar-(b)624-625 & $\mathrm{P}_{4}$ & Diaphysis & Medium & Worked bones & Bevel-cut instrument & 1 & & & 1 & & & 1 & \\
\hline \multirow[t]{2}{*}{ MLP-Ar-(b)598-600 } & $\mathrm{P}_{4}$ & Diaphysis & Medium & Worked bones & Flaked bone & 1 & & & 1 & 1 & & & \\
\hline & & & & & & 7 & 7 & 2 & 11 & 4 & 1 & 6 & \\
\hline
\end{tabular}




\begin{tabular}{|c|c|c|c|c|c|c|c|c|c|c|c|c|c|c|}
\hline \multirow[b]{2}{*}{ Number } & \multirow[b]{2}{*}{ Site } & \multirow[b]{2}{*}{ Element } & \multirow[b]{2}{*}{$\begin{array}{l}\text { Size / } \\
\text { identi- } \\
\text { fication }\end{array}$} & \multirow[b]{2}{*}{ Ameghino category } & \multirow[b]{2}{*}{$\begin{array}{l}\text { Specific function according } \\
\text { to Ameghino }\end{array}$} & \multicolumn{4}{|c|}{$\begin{array}{l}\text { Alternative } \\
\text { interpretation }\end{array}$} & \multicolumn{5}{|c|}{$\begin{array}{l}\text { Additional characteris- } \\
\text { tics of bone processing }\end{array}$} \\
\hline & & & & & & 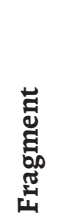 & $\begin{array}{l}\stackrel{\mathscr{z}}{\pi} \\
\frac{\pi}{4}\end{array}$ & 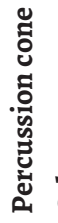 & 岂 & 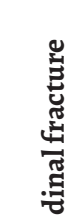 & 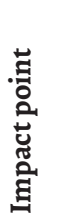 & 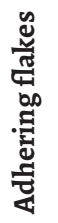 & 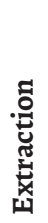 & 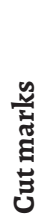 \\
\hline MLP-Ar-(b)659 & $\mathrm{P}_{2}$ & Diaphysis & Medium & Bone longitudinally broken & Bone broken for marrow extraction & 1 & & & & 1 & & & & \\
\hline MLP-Ar-(b)580 & $\mathrm{P}_{2}$ & $\begin{array}{l}\text { Rib } \\
\text { (juvenil) }\end{array}$ & $\begin{array}{l}\text { Pseudoles- } \\
\text { todon* }\end{array}$ & Bone with incisions & Cutmarked bone & & & & 1 & & & & & 1 \\
\hline MLP-Ar-(b)653 & $\mathrm{P}_{2}$ & Diaphysis & Toxodon* & Bone with incisions & Cutmarked bone & 1 & & & & 1 & 1 & & & \\
\hline MLP-Ar-(b)667-668 & $\mathrm{P}_{2}$ & - & - & Worked bones & Bevel-cut instrument & & 1 & & & 1 & & & & \\
\hline MLP-Ar-(b)630-631 & $\mathrm{P}_{2}$ & - & - & Worked bones & Arrowhead & & 1 & & & 1 & & & & \\
\hline MLP-Ar-(b)539 & $\mathrm{P}_{2}$ & Diaphysis & - & Worked bones & Awl & 1 & & & & 1 & 1 & & & \\
\hline MLP-Ar-(b)611 & $\mathrm{P}_{2}$ & Diaphysis & Medium & Worked bones & $\begin{array}{l}\text { Bone longitudinally broken } \\
\text { and stroked in both sides }\end{array}$ & 1 & & & & 1 & 1 & & 1 & \\
\hline MLP-Ar-(b)564-566 & $\mathrm{P}_{2}$ & Diaphysis & Small & Worked bones & $\begin{array}{l}\text { Instrument to be used for } \\
\text { cutting or as a scraper }\end{array}$ & & 1 & & & 1 & & & & \\
\hline MLP-Ar-(b)551-552 & $\mathrm{P}_{2}$ & Diaphysis & - & Worked bones & Instrument to be used for cutting & & & 1 & & & 1 & & 1 & \\
\hline MLP-Ar-(b)554-555 & $\mathrm{P}_{2}$ & Diaphysis & Medium & Worked bones & Instrument to be used for cutting & 1 & & & & 1 & 1 & & & \\
\hline MLP-Ar-(b)602-604 & & & & & & 6 & 3 & 1 & 2 & 8 & 6 & & 2 & 2 \\
\hline MLP-Ar-(b)646 & $P_{1}$ & Diaphysis & Small & Bone longitudinally broken & Broken bone for marrow extraction & 1 & & & & 1 & & & & 1 \\
\hline \multirow[t]{2}{*}{ MLP-Ar-(b)647 } & $\mathrm{P}_{1}$ & Diaphysis & Carnivore* $^{*}$ & Bone longitudinally broken & Broken bone for marrow extraction & 1 & & & & 1 & & & & \\
\hline & & & & & & 2 & & & & 2 & & & & 1 \\
\hline Total & & & & & & 21 & 12 & 3 & 2 & 29 & 14 & 2 & 9 & 3 \\
\hline
\end{tabular}

* Species identified by Ameghino.

** Element classified by Lehmann-Nitsche.

MLP-Ar-(b)601, MLP-Ar-(b)609, MLP-Ar-(b)634-635 and MLPAr-(b)626-627) to fragments produced for accessing marrow. For example, in MLP-Ar-(b)626-627 expansion waves in the impact point zone were observed as a result of the percussion strike. Bones MLP-Ar-(b)591-592 (Figure 2b) and MLPAr-(b)601, despite having sharp edges, were mainly the result of the percussion for breaking the bone. Both bones have clear impact points and an adhering flake was identified in MLP-Ar-(b)601. Bones MLP-Ar-(b)628/9 (Figure 2c) and MLPAr-(b)593-95 were identified as flakes, especially because of spiral fracture and their small dimensions.

\section{Paradero 4}

Bones from extinct megafauna such as Toxodon or mastodon and other smaller taxa were extracted from a lacustrine layer that was two meters below the surface of the Luján River (Figure 1). Sixteen diaphyses of medium and small mammals or indeterminate fragments were reviewed
(Table 1). According to Ameghino, diaphyses belonged to cervids and guanacos [11].

Several types of categories for the different modifications were described by the author. At the moment of the revision only bones belonging to "bones longitudinally broken" and "worked bones" were present in the collection. Regarding the first category, Ameghino mentioned 3 bones: MLP-Ar-(b)596, MLP-Ar-(b)581-582 and MLP-Ar-(b)612. Conchoidal cavities, depressions or longitudinal borders that could have been product of the percussion strikes, were identified in these fragments. Extractions or impact points are the current terminology to describe these features. In addition, in bone MLP-Ar-(b)612 clear expansion waves in one of the borders were observed (Figure 3a).

In the second category, "worked bones", there were also several sub-categories. Five bones could have been arrowheads and one an arrowhead or awl. Shape (MLP-Ar-(b)620, MLP-Ar-(b)621 and MLP-Ar-(b)640), symmetrical strikes 
a
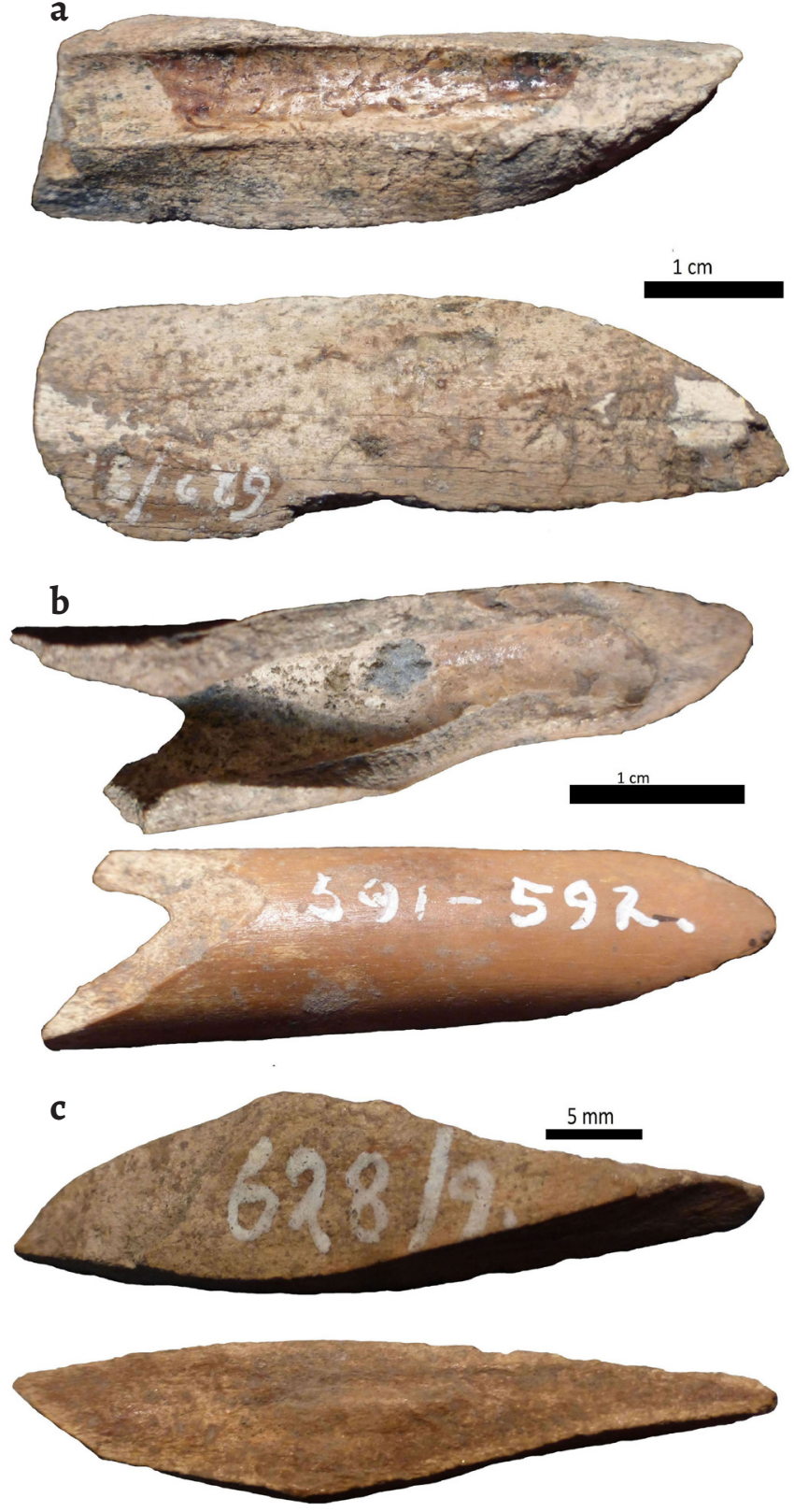

Figure 2. Cortical and medullar faces of bones from P5: $a$ ) MLPAr-(b)622/3 with root marks; b) MLP-Ar-(b)591-592; c) MLP-Ar-(b)628/9 flake.

(MLP-Ar-(b)562-563), artificial polish (MLP-Ar-(b)618) and intentional cuttings for producing a pointed edge (MLPAr-(b)540-541) were the features sustaining this categorization. Other six bones have been bevel-cut such as the MLPAr-(b)583 and the MLP-Ar-(b)585. Bone MLP-Ar-(b)553 also presented concavities and bones MLP-Ar-(b)559-561, MLPAr-(b)549-550, MLP-Ar-(b)624-625 had signs of specific strikes in their borders. Finally, bone MLP-Ar-(b)598-600 presented a different style of small strikes on its left side. In this category current interpretations do not match with the alleged functionality of the fragments. Regarding the six bones with an arrowhead (or awl) function, four would have been flakes (MLP-Ar-(b)620, MLP-Ar-(b)621, MLPAr-(b)640 and MLP-Ar-(b)562-563). Additionally, bone MLPAr-(b)621 had a clear adhering flake (Figure 3b), while the symmetrical strikes of MLP-Ar-(b)562-563 was reinterpreted
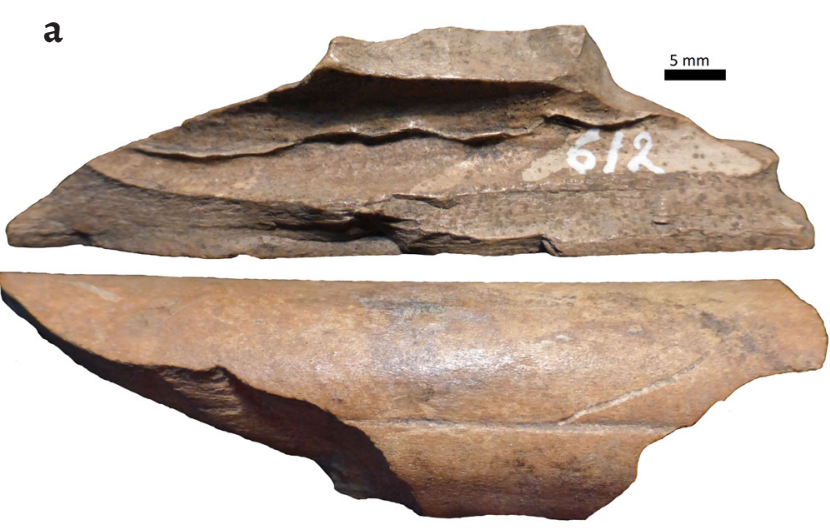

b
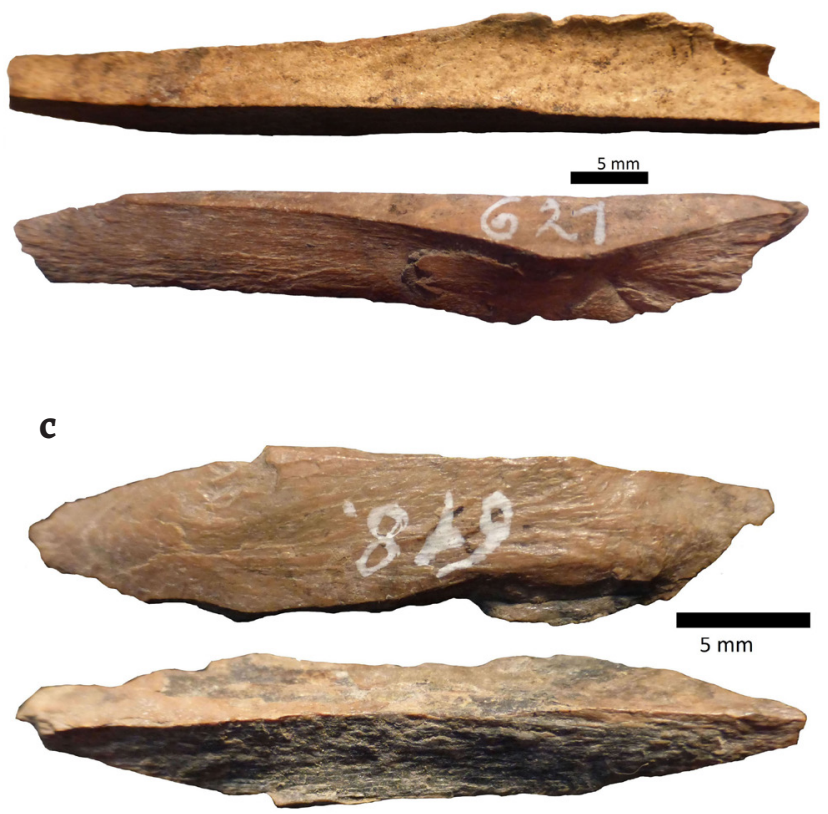

Figure 3. Cortical and medullar faces of bones from P4: a) MLPAr-(b)612; b) MLP-Ar-(b)621 with adhering flake; c) MLP-Ar-(b)618 percussion cone.

as an extraction. Bone MLP-Ar-(b)618 was actually a percussion cone with an impact point and circular waves (Figure 3c), while MLP-Ar-(b)540-541 was a fragment with extraction signs. The six bevel-cut bones were also interpreted in a different way. Bones MLP-Ar-(b)583, MLP-Ar-(b)585 and MLP-Ar-(b)553 would have been flakes, while the concavity observed in MLP-Ar-(b)553 would have been an extraction mark. Bone MLP-Ar-(b)559-561 would have been a percussion cone with a clear impact point in the cortical face (instead of the strike mentioned by Ameghino). Finally, bones MLPAr-(b)549-550 and MLP-Ar-(b)624-625 would have been fragments and only the last one presented extractions comparable to the blows observed by the author. Last but not least, bone MLP-Ar-(b)598-600 was probably a fragment, with two impact points. Nevertheless, it should not be ruled out that bones MLP-Ar-(b)562-563 and MLP-Ar-(b)540-541 may have had some type of functionality as the consecutive extractions shaped a pointed section in them. 


\section{Paradero 2}

According to Ameghino [11], it was one of the most important and ancient sites located in the Luján River (Figure 1) as he identified a big number of bones and species like cervids, guanacos, and megafauna such as Toxodon and Mylodon. Several types of evidences were described here, but currently only "bones longitudinally broken", "worked bones" and "bones with incisions" were located.

Twenty bones were examined, twelve of these presented clear features of percussion marks (Table 1). Eight bones could not be related with specific human traces like a metapod of Cervidae MLP-Ar-(b)655, as the observed longitudinal fractures did not have a smooth surface. He also described several cut marks on a Toxodon (MLP-Ar-(b)605) tooth and in the indeterminate diaphysis (MLP-Ar-(b)651). But the superficial and non-oriented marks match to the current descriptions of weathering and trampling cracks. Other bones (MLPAr-(b)597, MLP-Ar-(n)658, MLP-Ar-(b)586, MLP-Ar-(b)587, and MLP-Ar-(b)536) would have been used as arrowheads or awls given their polished and sharp edges. Currently, these fragments do not present clear biological interventions as the borders were post-depositionally broken, although the fluvial erosion observed in MLP-Ar-(b)597 could have been confused with an intentional polish as described by Ameghino. Apart from the metapod MLP-Ar-(b)655, bone MLP-Ar-(b)659 was also included into the "bones longitudinally broken" category. The spiral and smooth fractures observed can be related to the classification made by the author.

"Bones with incisions" were also present in this site, like the rib of a juvenile individual of Pseudolestodon (MLPAr-(b)580) that presented three oblique marks of approximately $1.5 \mathrm{~cm}$ on its internal face (Figure 4a). The marks described on a probable diaphysis of Toxodon (MLP-Ar-(b)653) were currently assigned to trampling marks, as these cross the entire surface in different directions and were superficially made. But the fact that a shallow loading point is present in one of the edges should not be ruled out.

Then, nine bones were assigned to the "worked bones" category. Different functions, manufacturing ways or species comprise this group. There was a possible tooth of Toxodon MLP-Ar-(b)606-607 that could have been extracted from a bigger tooth. There was also a bevel-cut bone the author described in detail (MLP-Ar-(b)667-668), a polished arrowhead (MLP-Ar-(b)630-631), a polished awl (MLP-Ar-(b)539), a bone that was first longitudinally broken and then stroked in both sides (MLP-Ar-(b)611), a cut and flaked bone to be used for cutting or as a scraper (MLP-Ar-(b)564-566) and two bones that were cut, polished and flaked to be used as cutting implements (MLP-Ar-(b)551-552 and MLP-Ar-(b)554-555). Into this category a possible rib (MLP-Ar-(b)602-604) was also included. It was entirely polished with a group of three oblique cut marks, two of $1 \mathrm{~cm}$ and one of $0.5 \mathrm{~cm}$ (Figure $4 \mathrm{~b}$ ). With the exception of this last element, up-to date information gave an alternative interpretation to the analysis carried out by Ameghino, as it occurred in the other sites. Four
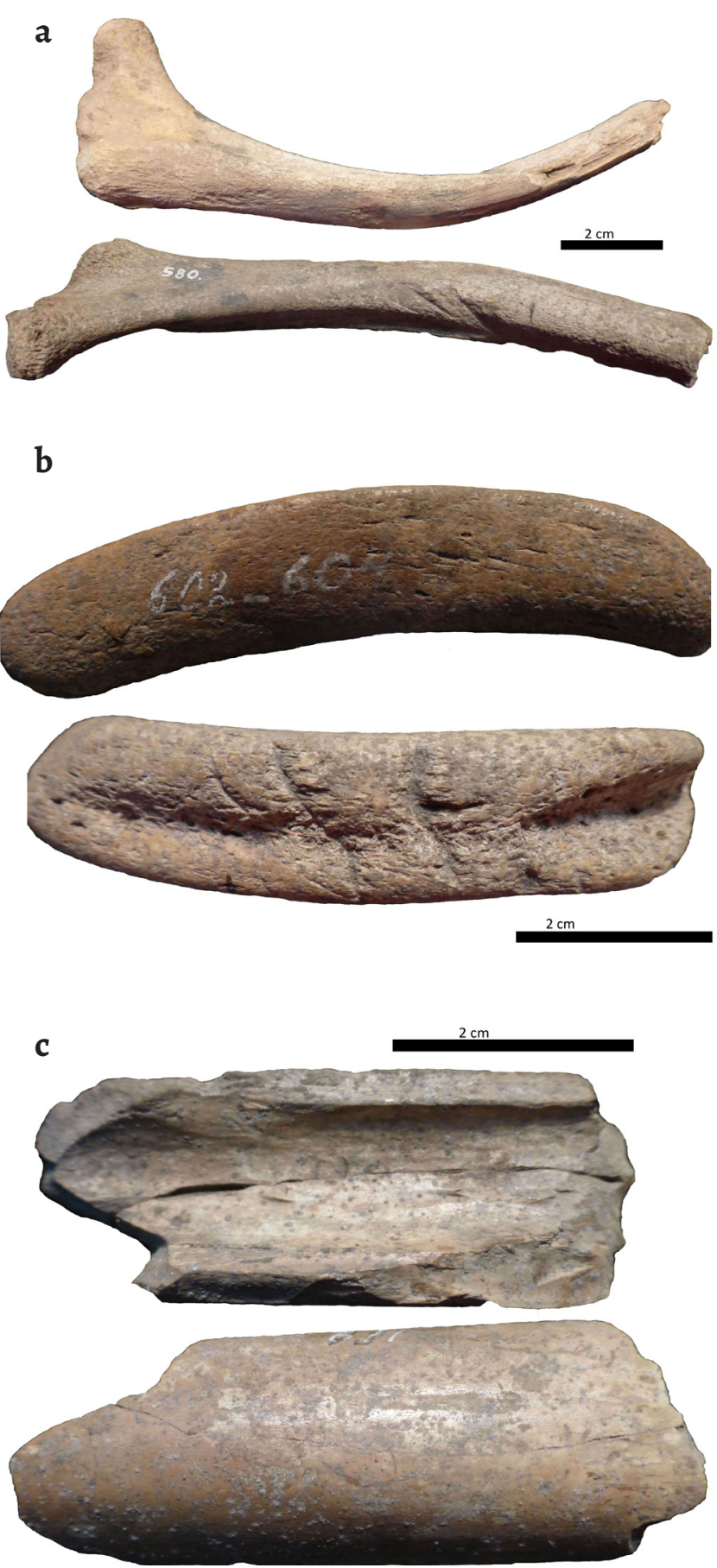

Figure 4. Bones from P2: a) MLP-Ar-(b)580 rib of Pseudolestodon with cut marks; b) MLP-Ar-(b)602-604 rib, polished and with cut marks; c) cortical and medullar faces of MLP-Ar-(b)611.

bones could have been fragments (MLP-Ar-(b)606-607, MLPAr-(b)539, MLP-Ar-(b)611 and MLP-Ar-(b)554-555). The first one, the possible tooth of Toxodon MLP-Ar-(b)606-607 was a fragment with an impact point on one side and some expansion waves as a result of the strike. Bone MLP-Ar-(b)539 was probably broken for marrow extraction and has one impact point with accompanying circular waves. The pointed shape on the opposite side could have had some type of function as stated by the author. Both borders of bone MLP-Ar-(b)611 had impact points, and on one side, two of them had circular 
waves extending into the cortical bone and an extraction follows one of them (Figure 4c). The diaphysis MLP-Ar-(b)554-555 was the result of the fragmentation for accessing the marrow. The important impact point observed in one of the borders could have been the result of this action. In addition, three bones could have been flakes (MLP-Ar-(b)667-668, MLP-Ar-(b)630-631 and MLP-Ar-(b)564-566) given their smaller size with spiral shapes, and bone MLP-Ar-(b)551-552 could have been a percussion cone with an impact point and cortical extractions.

\section{Paradero 1}

Ameghino discovered this site in the Frias stream in 1873 (Figure 1) and given the association of human remains with megafauna, he dedicated a special chapter in his work [11]. Nevertheless, only two diaphyses with spiral and longitudinal fractures and a possible cut mark in bone number MLP-Ar-(b)646 were reviewed in the collection. Bone MLPAr-(b)647 was attributed by Ameghino to a carnivore (Table 1). Recently the human bones have been dated in 10,300 \pm 60 and 9,520 \pm 75 14C BP (ca. 12,250 and 10,975 BC) [8], making this one of the earliest dates for human remains in the continent $[12,17]$.

\section{Discussion}

The Florentino Ameghino collection participated in one of the most important international controversies of the 19th century about human antiquity. The material presented here inspired Ameghino's first scientific postulates. Especially crucial for confirming an antique occupation of the Pampean region was the association of instruments intentionally produced for different activities and diverse megamammals taxa, into Tertiary levels. The general manufacturing procedure was to break the bones to access marrow and later on use the small fragments for different purposes such as arrows, scrapers or bevel-cut instruments. Abundance of bone fragments in the same levels and the alleged similarity in shapes were interpreted as evidences of anthropic manipulation for instruments production.

Nevertheless, in the 19th century the lack of a detailed corpus of methodologies and terminology influenced the way in which the faunal material analyses were made. Even at the time of Lehmann-Nitsche's revision, almost thirty years later, the corpus of bone modification studies had still not been fully developed. Thus, up-to-date archaeological information and methodologies can be used to clarify at least two misconceptions of this standpoint collection. On the one side, surface modifications of biological (both carnivore and humans) and non-biological origin were sometimes confused. On the other side, it was supposed that most of the bone fragments were produced for a specific task.

In relation to the first misconception some non-biological marks were attributed to a biological origin. In $\mathrm{P}_{5}$ bone
MLP-Ar-(b)622/3 with supposed rodent marks, they were actually roots. In P2, the tooth of Toxodon MLP-Ar-(b)605, the indeterminate diaphysis MLP-Ar-(b)651 and the diaphysis of Toxodon MLP-Ar-(b)653 included in the "bones with incisions" category had actually weathering and trampling marks, and bones MLP-Ar-(b)597, MLP-Ar-(n)658, MLP-Ar-(b)586, MLPAr-(b)587 and MLP-Ar-(b)536 included in the "worked bones" category, did not present clear anthropic modifications. In this sense, the development of specific methodologies and, considering post-depositional factors influencing the bone surface throughout the last decades is essential for detecting and separating biological from non-biological interventions. At the time of Ameghino, the lack of this type of information would have strongly influenced the interpretation of non-biological marks as biologically made.

Regarding the second misconception, the instruments described as "worked bones" cannot definitely be assigned to this category. The use of instruments during the Holocene of the region is well documented. The bones they were made with have clear signs of human elaboration for this purpose $[25,43]$. However, in the Florentino Ameghino collection fragments are small, with presence of impact points, extractions or adhering flakes. These characteristics show evidence of the process of blowing the bones for extracting the marrow, not for making tools. In relation to this observation, most of the long bones included in his category "bones longitudinally broken" could have been the result of this type of activity.

In spite of the bias of the sample, its analysis sheds light on how prehistoric subsistence was developed in the Luján River Basin. In this sense, the collection was affected by historical conditions added to the probable post-depositional factors affecting the sites. When excavating them, Ameghino observed that the material was left in situ for future excavations [11] so only a selected part of the material was extracted. Afterwards, the collection was misplaced more than one century ago and only a part of it has recently appeared. Thus, from the partial sample originally excavated, a smaller quantity has survived until today. For example, diaphyses of long bones are the predominant category for the appendicular skeleton, whereas epiphyses are absent. The axial skeleton is only represented by two ribs, and the cranial skeleton is represented by the supposed teeth of Toxodon. Nevertheless, thanks to this collection, it can be seen how this spot of the Pampean region was recurrently used. Similar activities were performed, as processing of different taxa and marrow extraction was done in the four sites. Additionally, the cut marks observed over the rib of Pseudolestodon found in P2 indicates consumption of juvenile megafauna. This evidence directly confirms Ameghino's claims of human-megafauna coexistence and the antiquity of these paraderos, despite not being of Tertiary age. Considering the early date obtained in P1, human occupation dates backs to the Late Pleistocene/Early Holocene in $\mathrm{P} 1$ and $\mathrm{P} 2$. 


\section{Conclusion}

Museum collections are a standpoint of modern archaeology. The materials that make them up were described and interpreted based on paradigms and ideas different from those of today. The technological, theoretical and practical archaeology has made great progress during the 2oth century which has enabled to go back to these collections and obtain new ideas for current and future research. Consequently, preserving and maintaining these foundational collections on the one side protects the historicity aspect in which they were conformed and discussed, and on the other it is a necessary issue to interconnect them in the current research axis.

The Florentino Ameghino collection at the Museo de La Plata is a practical example to see how this can be put into practice. More than one century after its extraction its revision was highly useful. It brought back the 19th century debate of human antiquity and gave renewed information from a current modified sector of the Luján River Basin. Also, it was a clear way to understand how museum collections can be reinterpreted and produce a new corpus of information for deciphering the past dynamics. The use of next-generation methodologies in this and other collections will allow having new information still to be discovered in this Cultural Heritage.

\section{Acknowledgments}

This essay was financed by the Erasmus Mundus grant inside the International Doctorate in Quaternary and Prehistory program. It is part of the PICT 2014-1558 Sociedades y Ambientes en Transformación funded by FONCYT-MINCYT, and of the project El Patrimonio Arqueológico $y$ Paleontológico de la Cuenca Superior del Río Luján: Investigación y Gestión, Resolution CD N ${ }^{\circ}$ 2830/16, Facultad de Filosofía y Letras, UBA. Thank you to José Luis Lanata, Sonia Lanzelotti, Gabriel Acuña Surez and Nadia Moschen for their critical reading and/or collaboration and Milagros Sicca for reviewing the English version of the manuscript. Thank you to the Museo de La Plata and especially to the curator Ana Igareta for allowing access to the collection. I am particularly thankful to two anonymous reviewers, whose comments and suggestions gave new ideas that were really useful for improving the text and figures.

\section{REFERENCES}

1. Grayson, D. K., The Establishment of Human Antiquity, Academic Press, New York (1983).

2. Goodrum, M. R., 'The history of human origins research and its place in the history of science: research problems and historiography', History of Science 47(3) (2009) 337-357, https://doi. org/10.1177/007327530904700305.

3. Podgorny, I., El Sendero del Tiempo y de las Causas Accidentales. Los Espacios de la Prehistoria en la Argentina, 1850-1910, Prohistoria ediciones, Rosario (2009).

4. Sackett, J., 'Boucher de Perthes and the discovery of human antiquity', Bulletin of the History of Archaeology 24 (2014) art. 2, https://doi.org/10.5334/bha.242.
5. Monjeau, J. A.; Araujo, B.; Abramson, G.; Kuperman, M. N.; Laguna, M. F.; Lanata, J. L., 'The controversy space on Quaternary megafaunal extinctions', Quaternary International 431 (2017) 194-204, https://doi.org/10.1016/j.quaint.2015.10.022.

6. O'Connor, A., 'Brixham cave \& the antiquity of man: reassessing the archaeological \& historical significance of a British cave site', Lithics 21 (2000) 20-28.

7. Podgorny, I., 'Bones and Devices in the Constitution of Paleontology in Argentina at the End of the Nineteenth Century', Science in Context 18 (2005) 249-283, https://doi. org/10.1017/S0269889705000475.

8. Meltzer, D. J., 'The antiquity of man and the development of American archaeology', in Advances in Archaeological Method and Theory, ed. M. B. Schiffer, vol. 6, Academic Press, New York (1983) 1-51, https://doi.org/10.1016/B978-0-12-003106-1.50006-7.

9. Pilo, L. B.; Auler, A. S.; Neves, W. A.; Wang, X.; Cheng, H.; Edwards, R. L., 'Revisitando a Lapa do Sumidouro: marco paleoantropológico do Quaternário americano', Revista Brasileira de Paleontologia, 7(3) (2004) 337-348.

10. Floria, P. N.; Salgado, L.; Azar, P., 'La invención de los ancestros: el «patagón antiguo» y la construcción discursiva de un pasado nacional remoto para la Argentina (1870-1915)', Revista de Indias 64(231) (2004) 405-424, https://doi.org/10.3989/revindias.2004.i231.546.

11. Ameghino, F., La Antigüedad del Hombre en el Plata, 2 vols., Masson-Igon Hermanos, Paris-Buenos Aires (1880-1881).

12. Lanzelotti, S. L.; Acuña Suarez, G. E., 'Actividad docente e investigaciones arqueológicas de Florentino Ameghino en Mercedes', in Florentino Ameghino en Mercedes: Homenaje en el Centenario de su Fallecimiento, ed. S. L. Lanzelotti \& G. E. Acuña Suarez, Museo Municipal de Ciencias Naturales 'Carlos Ameghino', Mercedes (2014) 111-130.

13. Toledo, M. J., 'Ameghino en contexto. Nuevos datos históricos y revisión geoarqueológica del sitio Arroyo Frías (18701874): Mercedes, provincia de Buenos Aires, Argentina', Revista del Museo Argentino de Ciencias Naturales 18(2) (2016) 147-187, https://doi.org/10.22179/REVMACN.18.460.

14. Lanzelotti, S. L., 'Arqueología del partido de Mercedes y sus alrededores'. Proyecto, Dirección Provincial de Patrimonio Cultural de la provincia de Buenos Aires, 2008-3-A-151-1 (2008).

15. Hrdlička, A., Early Man in South America, Smithsonian Institution, Bureau of American Ethnology, Washington, D.C. (1912).

16. Podgorny, I.; Politis, G. G., 'It is not all roses here: Ales Hrdlička's travelog and his visit to Buenos Aires in 1910', Nova Revista de História da Arte e Arqueologia 3 (2000) 95-105.

17. Politis, G. G.; Bonomo, M., 'Nuevos datos sobre el 'hombre fósil' de Ameghino', in Vida y Obra de Florentino Ameghino, Publicación especial, ed. J. C. Fernicola, A. R. Prieto \& D. G. Lazo, vol. 12, Asociación Paleontológica Argentina, Buenos Aires (2011) 101-119.

18. Podgorny, I., 'Human origins in the New World? Florentino Ameghino and the emergence of prehistoric archaeology in the Americas (1875-1912)', PaleoAmerica 1(1) (2015) 68-80, https://doi.org/10.1179/2055556314Z.0000000008. 
19. Mengoni Goñalons, G. L., 'Archaeofaunal studies in Argentina: a historical overview', in Taphonomy and Zooarchaeology in Argentina, ed. M. A. Gutiérrez, G. Barrientos, G. L. Mengoni Goñalons, L. Miotti. \& M. Salemme, BAR International, Oxford (2007) 13-34.

20. Chichkoyan, K. V.; Martínez-Navarro, B.; Moigne, A. M.; Belinchón, M.; Lanata, J. L., 'The exploitation of megafauna during the earliest peopling of the Americas: An examination of nineteenth-century fossil collections', Comptes Rendus Palevol 16(4) (2017) 440-451, https://doi.org/10.1016/j. crpv.2016.11.003.

21. Lyman, R. L., Vertebrate Taphonomy. Cambridge Manuals in Archaeology, Cambridge University Press, Cambridge (1994).

22. Yravedra, J., Tafonomía aplicada a Zooarqueología, UNED, Madrid (2013).

23. Allmon, W. D., 'Collections in paleontology', in Paleontology in the 21st Century Workshop: International Senckenberg Conference, ed. H. R. Lane, J. Lipps, F. F. Steininger \& W. Ziegler, Kramer, Frankfurt (1997) 155-159.

24. Pérez de Micou, C., 'Las colecciones arqueológicas y la investigación', Revista do Museu de Arqueologia e Etnologia 8 (1998) 223-233, https://doi.org/10.11606/issn.2448-1750. revmae.1998.109543.

25. Bonomo, M.; Capdepont, I.; Matarrese, A., 'Alcances en el estudio de colecciones. Los materiales arqueológicos del Delta del Río Paraná depositados en el Museo de La Plata (Argentina)', Revista de Arqueología Sudamericana 5 (2009) 68-101.

26. Cristín, A.; Perrilliat, M. D. C., 'Las colecciones científicas y la protección del patrimonio paleontológico', Boletín de la Sociedad Geológica Mexicana 63(3) (2011) 421-427, http://www. scielo.org.mx/scielo.php?script=sci_arttext\&pid=S140533222011000300004\&lng=es\&nrm=iso (accessed 2019-5-20).

27. Huster, A. C., 'Assesing Systematic bias in Museum Collections. A case study of Spindle Whorls', Advances in Archaeological Practice: A Journal of the Society for American Archaeology 1(2) (2013) 77-90, https://doi.org/10.7183/23263768.1.2.77.

28. Martin, F., M., 'Cueva del Milodón. The hunting grounds of the Patagonian panther'. Quaternary International 466(B) (2018) 212-222, https://doi.org/10.1016/j.quaint.2016.05.005.

29. Cadee, G. C., 'The history of taphonomy', in The Processes of Fossilization, ed. S. K. Donovan, Columbia University Press, New York (1991) 3-21.

30. Sholts, S. B.; Bell, J. A.; Rick, T. C., 'Ecce Homo: science and society need anthropological collections', Trends in ecology \&Evolution 31(8) (2016) 580-583, https://doi.org/10.1016/j. tree.2016.05.002.

31. Catalá Gorgues, J. I., ‘¿Absolutamente sin cuidado?: Juan Vilanova y la polémica sobre el Hombre terciario', Asclepio 63(2) (2011) 379-404, https://doi.org/10.3989/asclepio.2011.v63.i2.498.

32. Salgado, L.; Azar, P. F., 'Nuestro lugar entre los primates. Un resumen de las principales ideas de Florentino Ameghino sobre la evolución humana', Saber y Tiempo 15(2003) 05-18.

33. Pomi, L. H.; Tonni, E. P. 'La utilización temprana de herramientas tafonómicas: Leonardo Da Vinci y Florentino Ameghino', Serie Correlación Geológica 24 (2008) 55-62, http:// www.scielo.org.ar/scielo.php?script=sci_arttext\&pid=S166694792008000200006\&lng=es\&nrm=iso (accessed 2019-5-20).
34. Fisher, J. W. Jr., 'Bone surface modifications in zooarchaeology', Journal of Archaeological Method and Theory 2(1) (1995) 7-68, https://doi.org/10.1007/BFo2228434.

35. Fernández-Jalvo, Y.; Andrews P., Atlas of Taphonomic Identifications. 1001+ Images of Fossil and Recent Mammal Bone Modification, Springer Publishers, Dordrecht (2016).

36. Farro, M. E., 'Historia de las colecciones en el Museo de La Plata, 1884-1906: naturalistas viajeros, coleccionistas y comerciantes de objetos de historia natural a fines del Siglo XIX', PhD thesis, Facultad de Ciencias Naturales y Museo, La Plata (2008).

37. Alexander, E. P.; Alexander, M.; Decker, J., Museums in Motion: An Introduction to the History and Functions of Museums, 3rd ed., Rowman \& Littlefield, Maryland (2017).

38. Le Cabec, A.; Toussaint, M., 'Impacts of curatorial and research practices on the preservation of fossil hominid remains', Journal of Anthropological Sciences 95 (2017), 7-34, https://doi.org/10.4436/JASS.95002.

39. Suarez, A. V.; Tsutsui, N. D., 'The value of museum collections for research and society', BioScience 54(1) (2004) 66-74, https:// doi.org/10.1641/0006-3568(2004)054[0066:TVOMCF]2.0.CO;2.

40. Cenizo, M. M.; Soibelzon, E.; Tonni, E. P., 'Protección de costas y pérdida del patrimonio paleontológico: el caso de Punta Hermengo (Miramar, provincia de Buenos Aires)', Revista del Museo de La Plata, Sección Paleontología 11(63) (2011) 1-16, https:// publicaciones.fcnym.unlp.edu.ar/rmlp/article/view/2188 (accessed 2019-5-20).

41. Collazo, J., 'Avances de la puesta en valor de las colecciones del depósito 25 del Museo de la Plata. A casi 4 años de trabajo ininterrumpido', in I Congreso Latinoamericano y II Congreso Nacional de Museos Universitarios, La Plata (2013) 1-12, http:// hdl.handle.net/10915/42463.

42. Lehmann-Nitsche, R. 'Nouvelles recherches sur la formation pampéenne et l'homme fossile de la République Argentine' Revista del Museo de La Plata 14 (1907) 143-488.

43. Buc, N.; Loponte, D., 'Bone tools reflecting animal exploitation. The case of Lama guanicoe in the lower Paraná basin', Cuadernos del Instituto Nacional de Antropología y Pensamiento Latinoamericano, Series Especiales 3(2) (2016) 23-53, http://ppct.caicyt.gov.ar/index.php/cinapl-se/article/ view/10058/9083.

RECEIVED: 2018.6.18

REVISED: 2019.3 .31

ACCEPTED: 2019.4.22

ONLINE: 2019.6 .5

\section{(c) (i) $\odot$}

This work is licensed under the Creative Commons

Attribution-NonCommercial-NoDerivatives 4.0 International License.

To view a copy of this license, visit

http://creativecommons.org/licenses/by-nc-nd/4.o/deed.en. 